\title{
Performance Evaluation and Application of Banking Industry Based on Equator Principles
}

\author{
Yutong Tang ${ }^{1, \mathrm{a}}$, Yan Zhou ${ }^{2, \mathrm{~b}}$ \\ ${ }^{1}$ School of Economics and Management, Nanjing University of Science and Technology, NanJing, China \\ ${ }^{2}$ School of Economics and Management, Nanjing University of Science and Technology, NanJing, China
}

\begin{abstract}
With the deterioration of the global natural and social environment, people have begun to pay attention to the fulfillment of corporate social responsibility, and banks as special financial institutions are no exception. In 2003, the emergence of the Equator Principle became the basic criterion for the banking industry to fulfill its social responsibility. Under such a social trend, China's banking industry proposed a "green credit" policy in 2007, but it is still far from the equatorial principles introduced internationally. Therefore, how to accelerate the pace of China's banking industry entering the Equator Bank is a question worth considering. We need to set up a bank performance evaluation system based on the equator principle to promote the development of the equator principle in China's banking industry, which is also the focus of this article. In this paper, through the study of the practice of the Equator Principles at home and abroad, a set of performance evaluation systems for the banking industry based on the Equator Principles is established. The Industrial Bank is used as an example to apply this evaluation system.
\end{abstract}

\section{INTRODUCTION}

The Equator Principles are an unofficial regulation designed by the world's leading financial institutions in accordance with IFC's environmental and social policies and guidelines. They are designed to provide minimum standards for due diligence to encourage corporate social responsibility risk management principles. The equatorial principle arises mainly from internal and external pressures on financial institutions to fulfill corporate social responsibility. When the financing provided by a bank to an enterprise has a negative impact on society and the environment, it will cause a loss of reputation for the bank itself. Stakeholders believe that banks are obliged to conduct a careful investigation of environmental and social issues in project financing and take corresponding measures to exert pressure on enterprises to urge them to reduce the negative effects on the environment and society.

As a financial intermediary in a country, banks are the masters of the operation mechanism of social funds, and they play an important role in the Chinese economy. And performance management is one of the key factors determining the core competitiveness of banks. Appropriate and advanced performance evaluation systems for commercial banks are conducive to the establishment of a sound incentive and restraint mechanism for commercial banks to improve their level of management and overall competitiveness. Therefore, the status of performance evaluation in the banking industry is becoming increasingly important.
However, the performance evaluation system of most banks in China still takes profit maximization as its core goal and turns a blind eye to environmental and social issues. They believe that these issues have nothing to do with their interests. But it is certain that in recent years, China's banking industry has also gradually realized the important impact of environmental and social risk issues on itself, of which "green credit" is the product of development. However, we must see that China's banking industry is still in its infancy in terms of international practices such as the Equator Principles. Therefore, it is necessary to incorporate the equatorial principle into the performance evaluation of the banking industry, and to establish an appropriate performance evaluation system, which is also the main content of this paper.

\section{Comparison of Equator Principles Used by Domestic and Foreign Banking Industry}

\subsection{Foreign Practices of the Equator Principles}

In June 2003, 10 major banks, including 4 originating banks, announced the implementation of the Equator Principles. Since then, the Equator Principles have been applied to major financing projects, such as the Baku-Tbilisi-Ceyhan (BTC) pipeline project, the Sakhalin-2 oil and gas development project ( the Sakhalin II oil and gas project), the Narmada Dam project in India. As of December 2007, 56 financial

a408625126@qq.com; byyang77@126.com 
institutions have announced the implementation of the Equator Principles, and their project financing accounts for more than $80 \%$ of the global total. Among them, Asia started late as a whole. As the first equatorial bank in Asia, Mizuho Industrial Bank of Japan has played a certain role in promoting the implementation of the equatorial principles in the entire Asian banking industry. From the development after that, it can be seen that the equatorial principles have an impact on bank performance positive effects.

According to the World Bank rankings in 2016, only six of the top twenty are not Equator, and five of them are from China.

\subsection{Status of Domestic Practice of the Equator Principles}

Compared with other countries, China has relatively few practices on the equatorial principle and is still basically in the preliminary exploration stage. In terms of environmental risk control in China's current banking industry, most of them implement green credit policies in accordance with the "Guiding Opinions on Improving and Strengthening Financial Services in the Field of Energy Conservation and Environmental Protection" issued by the People's Bank of China in 2007, but there is still a certain gap between green credit and the equator principle. As of February 2017, only China Industrial Bank and Bank of Jiangsu have accepted the Equator Principles.

Industrial Bank's performance has grown rapidly after joining the Equator Bank. In the "2016 Global Banking Brands Top 500 List" released by the British "The Banker", Industrial Bank ranked 36th with a brand value of US \$ 6.455 billion, a sharp rise of 19 places from the previous ranking and entering the global banking brand Top 50. At the same time, Industrial Bank was also selected as one of the top ten "Wholesale and Commercial Banks" with the highest global brand value in 2016.

On January 20, 2017, Bank of Jiangsu announced that it had joined Equator Bank, becoming the first city commercial bank to join the Equator Principles in China, and the second Equator Bank in China after Industrial Bank. Its participation has been widely praised by the industry, and has played a leading role in the model. It has also added momentum for more banks to follow up.

It is not difficult to find that the adoption of the Equator Principles has a great positive impact on the development of banks.

\section{Performance Evaluation System of Banking Industry Based on Equator Principles}

The Equator Principles play a very important role in fulfilling social responsibilities of banks. The Equator Principles emphasize the common sustainable development of banks, society and the environment. Banks adopting the Equator Principles have shown significant advantages among their peers over time.
However, China's implementation of the equatorial principle is still behind. From the current point of view, building a bank performance evaluation system that includes the equator principle is one of the most effective ways to promote the fulfillment of social responsibilities by the banking industry in China, and it is also the key to promoting China's sustainable development.

The traditional performance evaluation system of the banking industry takes profit maximization as the core, and indexes profitability, development ability status, asset quality status, and operating capacity while neglecting the performance of social responsibility. Today's research on social responsibility performance evaluation systems includes social responsibility into the first-level indicators, and environmental factors into the second-level indicators. This article further clarifies the environmental factors, and regards project financing based on the equator principle as the secondary indicator of the system.

\subsection{Constructing a Bank Performance Evaluation System Based on the Equator Principles}

\subsubsection{Theoretical basis}

The performance evaluation system constructed in this paper is mainly based on the theory of stakeholders, which believes that the development of any company cannot be separated from the input or participation of various stakeholders, the company is pursuing the overall interests of stakeholders, not only the interests of certain subjects. Stakeholders include trading partners such as shareholders, creditors, employees, consumers, and suppliers of enterprises, as well as pressure groups such as government departments, local residents, local communities, media, environmentalism, and even natural environments, human offspring, etc. Objects directly or indirectly affected by business operations. Business decisions must consider their interests or accept their constraints. This theory is the center of corporate performance evaluation. As banks are special enterprises, stakeholder theory is also applicable to them.

\subsubsection{Selection of performance evaluation indicators}

Follow the basic principles and theoretical basis to choose the first-level and second-level indicators.

The calculation formula of each indicator is shown in the following table:

Table 1 Evaluation Index Table

\begin{tabular}{|c|c|c|}
\hline $\begin{array}{c}\text { Primary } \\
\text { index }\end{array}$ & Secondary index & $\begin{array}{c}\text { Calculation } \\
\text { formula }\end{array}$ \\
\hline $\begin{array}{c}\text { Responsibilit } \\
\begin{array}{c}\mathrm{y} \text { to } \\
\text { shareholders } \\
\mathrm{w}_{1}\end{array}\end{array}$ & $\begin{array}{c}\text { Return on } \\
\text { investment } \mathrm{w}_{11}\end{array}$ & $\begin{array}{c}\text { Operating } \\
\text { profit } / \\
\text { operating } \\
\text { assets }\end{array}$ \\
\cline { 2 - 3 } & Return on equityw $\mathrm{w}_{12}$ & $\begin{array}{c}\text { Net profit / } \\
\text { average net }\end{array}$ \\
\hline
\end{tabular}




\begin{tabular}{|c|c|c|}
\hline & & assets \\
\hline & NPL ratio $\mathrm{w}_{13}$ & $\begin{array}{l}\text { NPL amount } \\
/ \text { total loans }\end{array}$ \\
\hline \multirow[t]{3}{*}{$\begin{array}{l}\text { Liability to } \\
\text { customers } \mathrm{w}_{2}\end{array}$} & $\begin{array}{l}\text { Asset-liability ratio } \\
\mathrm{w}_{21}\end{array}$ & $\begin{array}{c}\text { otal liabilities } \\
\text { / total assets }\end{array}$ \\
\hline & $\begin{array}{l}\text { Customer Complaint } \\
\text { Handling Rate } \quad w_{22}\end{array}$ & $\begin{array}{l}\text { Complaints } \\
\text { Handled / } \\
\text { Total } \\
\text { Complaints }\end{array}$ \\
\hline & $\begin{array}{l}\text { Number of business } \\
\text { establishments } w_{23}\end{array}$ & $\begin{array}{c}\text { Number of } \\
\text { business } \\
\text { establishmen } \\
\text { ts }\end{array}$ \\
\hline \multirow[t]{4}{*}{$\begin{array}{c}\text { Responsibilit } \\
\text { y to } \\
\text { employees } \\
\mathrm{w}_{3}\end{array}$} & $\begin{array}{l}\text { Wages per } \\
\text { employeew } 31\end{array}$ & $\begin{array}{c}\text { Total } \\
\text { compensatio } \\
\mathrm{n} / \text { Number } \\
\text { of employees }\end{array}$ \\
\hline & $\begin{array}{l}\text { Employee salary } \\
\text { growth rate } \mathrm{w}_{32}\end{array}$ & $\begin{array}{l}\text { Employee } \\
\text { salary } \\
\text { increase for } \\
\text { the current } \\
\text { year / } \\
\text { employee } \\
\text { salary for the } \\
\text { previous year }\end{array}$ \\
\hline & Welfare level $\mathrm{w}_{33}$ & $\begin{array}{l}\text { Welfare fee / } \\
\text { Total cost }\end{array}$ \\
\hline & $\begin{array}{l}\text { Staff training } \\
\text { inputw }\end{array}$ & $\begin{array}{c}\text { Staff training } \\
\text { expenditure / } \\
\text { main } \\
\text { business } \\
\text { income }\end{array}$ \\
\hline \multirow{3}{*}{$\begin{array}{l}\text { Responsibilit } \\
\text { y to the } \\
\text { government } \\
\mathrm{w}_{4}\end{array}$} & Asset tax rate $\mathrm{w}_{41}$ & $\begin{array}{l}\text { Total tax / } \\
\text { total average } \\
\text { assets }\end{array}$ \\
\hline & $\begin{array}{c}\text { Social Contribution } \\
\text { Ratew } 42\end{array}$ & $\begin{array}{c}\text { Total Social } \\
\text { Contribution } \\
\text { / Total } \\
\text { Average } \\
\text { Assets } \\
\end{array}$ \\
\hline & $\begin{array}{c}\text { Employment } \\
\text { contribution ratew }\end{array}$ & $\begin{array}{l}\text { Cash paid to } \\
\text { employees } \\
\text { and average } \\
\text { net assets }\end{array}$ \\
\hline \multirow{2}{*}{$\begin{array}{l}\text { Responsibilit } \\
\text { y to the } \\
\text { community } \\
w_{5}\end{array}$} & $\begin{array}{l}\text { Donation income } \\
\text { ratio } W_{51}\end{array}$ & $\begin{array}{c}\text { Total } \\
\text { donations / } \\
\text { total income }\end{array}$ \\
\hline & $\begin{array}{c}\text { Equator Principles } \\
\text { Project Financing } \\
\text { Ratio } \mathrm{w}_{52}\end{array}$ & $\begin{array}{c}\text { Loan } \\
\text { Amount / } \\
\text { Total Loan in } \\
\text { Equator } \\
\text { Principles } \\
\end{array}$ \\
\hline
\end{tabular}

\subsubsection{Weight setting of performance evaluation index system}

After the preliminary establishment of the banking industry performance evaluation index system based on the equator principle, the next step should be to select an appropriate method to determine the weights of the primary and secondary indicators, and then form a complete performance evaluation system.

This article will use the Analytic Hierarchy Process (AHP) to determine the index weights at all levels. A questionnaire survey was conducted among 12 scholars from universities in Jiangsu Province. Different scholars will give different judgments. Finally, the highest and lowest scores of the survey results will be averaged, and the corresponding weights will be calculated. The results are as follows:

Table 2 Indicator weight table

\begin{tabular}{|c|c|c|c|}
\hline Primary index & weight & $\begin{array}{l}\text { Secondary } \\
\text { index }\end{array}$ & $\begin{array}{l}\text { weighted } \\
\text { weight }\end{array}$ \\
\hline \multirow[t]{3}{*}{$\begin{array}{l}\text { Responsibility } \\
\text { to shareholders } \\
\mathrm{w}_{1}\end{array}$} & \multirow[t]{3}{*}{0.08} & $\begin{array}{l}\text { Return on } \\
\text { investment } \\
\mathrm{W}_{11}\end{array}$ & 0.0136 \\
\hline & & $\begin{array}{l}\text { Return on } \\
\text { equityw } w_{12}\end{array}$ & 0.0280 \\
\hline & & $\begin{array}{l}\text { NPL ratio } \\
\mathrm{W}_{13}\end{array}$ & 0.0384 \\
\hline \multirow[t]{3}{*}{$\begin{array}{l}\text { Liability to } \\
\text { customers } \mathrm{w}_{2}\end{array}$} & \multirow[t]{3}{*}{0.17} & $\begin{array}{l}\text { Asset-liabil } \\
\text { ity ratio } \\
\mathrm{W}_{21}\end{array}$ & 0.0272 \\
\hline & & $\begin{array}{l}\text { Customer } \\
\text { Complaint } \\
\text { Handling } \\
\text { Rate } \quad \text { W}_{22}\end{array}$ & 0.0918 \\
\hline & & $\begin{array}{l}\text { Number of } \\
\text { business } \\
\text { establishm } \\
\text { ents } \mathrm{w}_{23}\end{array}$ & 0.1190 \\
\hline \multirow[t]{4}{*}{$\begin{array}{l}\text { Responsibility } \\
\text { to employees } \\
\mathrm{W}_{3}\end{array}$} & \multirow[t]{4}{*}{0.13} & $\begin{array}{l}\text { Wages per } \\
\text { employeew } \\
31\end{array}$ & 0.0143 \\
\hline & & $\begin{array}{l}\text { Employee } \\
\text { salary } \\
\text { growth rate } \\
\mathrm{W}_{32}\end{array}$ & 0.0247 \\
\hline & & $\begin{array}{l}\text { Welfare } \\
\text { level w } 33\end{array}$ & 0.0377 \\
\hline & & $\begin{array}{l}\text { Staff } \\
\text { training } \\
\text { inputw34 }\end{array}$ & 0.0533 \\
\hline \multirow{3}{*}{$\begin{array}{l}\text { Responsibility } \\
\text { to the } \\
\text { governmentw } 4\end{array}$} & \multirow[t]{3}{*}{0.31} & $\begin{array}{l}\text { Asset tax } \\
\text { rate } \mathrm{w}_{41}\end{array}$ & 0.0496 \\
\hline & & $\begin{array}{l}\text { Social } \\
\text { Contributio } \\
\text { n Ratew }\end{array}$ & 0.0930 \\
\hline & & $\begin{array}{l}\text { Employme } \\
\text { nt } \\
\text { contributio } \\
\text { n ratew } 43\end{array}$ & 0.1647 \\
\hline \multirow[t]{2}{*}{$\begin{array}{l}\text { Responsibility } \\
\text { to the } \\
\text { community } \mathrm{w}_{5}\end{array}$} & \multirow[t]{2}{*}{0.31} & $\begin{array}{l}\text { Donation } \\
\text { income } \\
\text { ratio } \mathrm{w}_{51}\end{array}$ & 0.0775 \\
\hline & & $\begin{array}{l}\text { Equator } \\
\text { Principles } \\
\text { Project } \\
\text { Financing } \\
\text { Ratio } \mathrm{W}_{52}\end{array}$ & 0.2325 \\
\hline
\end{tabular}

\subsubsection{Fuzzy comprehensive evaluation method}

Fuzzy comprehensive evaluation method is a comprehensive evaluation method based on fuzzy mathematics. This comprehensive evaluation method converts qualitative evaluation to quantitative evaluation according to the membership theory of fuzzy mathematics, that is, uses fuzzy mathematics to make an overall evaluation of things or objects subject to multiple factors. It has the characteristics of clear results and strong systemicity. It can solve fuzzy and difficult to quantify problems, and is suitable for solving various non-deterministic problems. Due to its complexity and 
uncertainty, the performance of the banking industry needs to be evaluated using fuzzy comprehensive evaluation methods after constructing the performance evaluation indicators of the banking industry.

\section{Application of Banking Performance Evaluation Based on the Equator Principle-Taking Industrial Bank as an Example}

\subsection{Basic situation of Industrial Bank's implementation of the Equator Principles}

Industrial Bank is the first bank in China to join the Equator Principles Agreement. According to the interim development report of the Industrial Bank, it learned that in 2019, the Bank carried out a judgment on the applicability of the Equator Principles on 45 projects and identified 41 projects that applied the Equator Principles. The total investment of the project is 138 billion yuan. Among them, a total of 12 projects applying the Equator Principles have reached the formal effective financing stage, and 12 project loans have been withdrawn from the market, with a total of 7.378 billion yuan. As of December 31, 2019, the bank had judged the applicability of the equatorial principle on 899 projects, with a total investment of RMB 2.261421 trillion. Among them, a total of 258 projects to which the Equator Principles were applied, involving a total investment of 564.5 billion yuan, involving 223 customers, and a total of 24.064 billion yuan of closed stocks.

\subsection{Industrial Bank's Fuzzy Comprehensive Evaluation of Bank Performance Based on the Equator Principles}

Aiming at the performance of Industrial Bank in 2019, according to the equator principle-based banking performance evaluation system established in this article, 10 experts were invited to evaluate it, and a fuzzy evaluation matrix was constructed.

The set of comments on the performance of the banking industry in this article is $\mathrm{V}=(\mathrm{V} 1, \mathrm{~V} 2, \mathrm{~V} 3, \mathrm{~V} 4$, V5) respectively (excellent, good, average, poor, poor), and the scores are set to $(100,80,60,40), 20)$.

The comprehensive evaluation results obtained are as follows:

The ratio of "excellent" to Industrial Bank's shareholders' evaluation is $41.8 \%$, "good" is $36.9 \%$, "fair" is $11.3 \%$, "poor" is $10 \%$, "poor" is 0 , and the score is 82.1; The customer's responsibility evaluation is "excellent" at $51.4 \%$, "good" is $24.4 \%$, "fair" is $13.2 \%$, "poor" is $7.8 \%$, "poor" is $3.2 \%$, and the score is 82.6 ; responsibility to employees The ratio of "excellent" was $37.6 \%$, "good" was $30.1 \%$, "fair" was $23 \%$, "poor" was $5.2 \%$, "poor" was $4.1 \%$, and the score was 78.38 ; the government's responsibility evaluation was "excellent" "The ratio is" $32.2 \%$ "," good "is $36 \%$," fair "is $28.6 \%$," poor "is $1.6 \%$," poor "is $1.6 \%$, and the score is 79.12 ; the percentage of community responsibility evaluation is" excellent " It is $65 \%$, "good" is $32.5 \%$, "fair" is $2.5 \%$, "poor" is 0 , "poor" is 0 , and the score is 92.5 .

The comprehensive evaluation of Industrial Bank was $47.1 \%$, "Good" was $32.2 \%$, "Fair" was $16.7 \%$, "Poor" was 3.3\%, and "Poor" was $1.6 \%$; the overall score was 84.52.

Through the above-mentioned fuzzy comprehensive evaluation of the Industrial Bank's performance, the Industrial Bank's comprehensive score is 84.52 , which is an excellent grade.

\section{Conclusion}

From the evaluation scores of the performance of responsibilities in various aspects, we can see that it has a significant advantage in the performance of community responsibilities, especially in the implementation of the equatorial principle, which has been highly evaluated by experts. The adoption of the Equator Principles has largely promoted the improvement of Industrial Bank's performance, which has made it develop rapidly in recent years, and it is also conducive to accelerating the pace of adoption of the Equator Principles by the entire banking industry. Establishing a performance evaluation system for the banking industry based on the equator is the key to promoting this.

\section{References}

1. Schepers DH. The Equator Principles: a promise in progress [J]. Corporate Governance. 2011. 11 (1).

2. Missbach A. The Equator Principles: Drawing the line for socially responsible banks? An interim review from an NGO perspective [J]. Development. 2004. 47 (3): 78-84.

3. Zhang Changlong. Environmental and Social Standards in International Financing: Equator Principles [J]. Finance Forum. 2006. 11 (5): 45-51.

4. Cheng Fanshen. Enlightenment of International Practice of "Equator Principles" to China [J]. Yangtze River Delta. 2008. 5 (9): 59-60.

5. Gao Shan. Research on the Equator Principles and the Development of Commercial Banks [J]. North China Finance. 2009. (6): 32-35.

6. Feng Shouzun, Chen Sheng. Equator Principle: Dream or Nightmare of Sustainable Development of Financial Industry [J]. Wuhan Finance. 2009. (11): 11-14.

7. Guo Qingma. The Path Choice of China's Commercial Banks to Implement the Equator Principles [J]. Finance and Economics. 2010. (6): 10-16.

8. Zhang Yan, Shi Shengjie. Analysis of Green Credit Legal System to Promote the Development of Low-Carbon Agriculture-Based on Financial Institutions' Practice of the Equator Principles [J]. Agricultural Modernization Research. 2013. 34 (6).

9. Ma Feifei, Du Chaoyun. Is the Equator Principle beneficial to the operating efficiency of China's 
commercial banks: Taking Industrial Bank as an example [J]. Contemporary Finance, 2015, (7). 